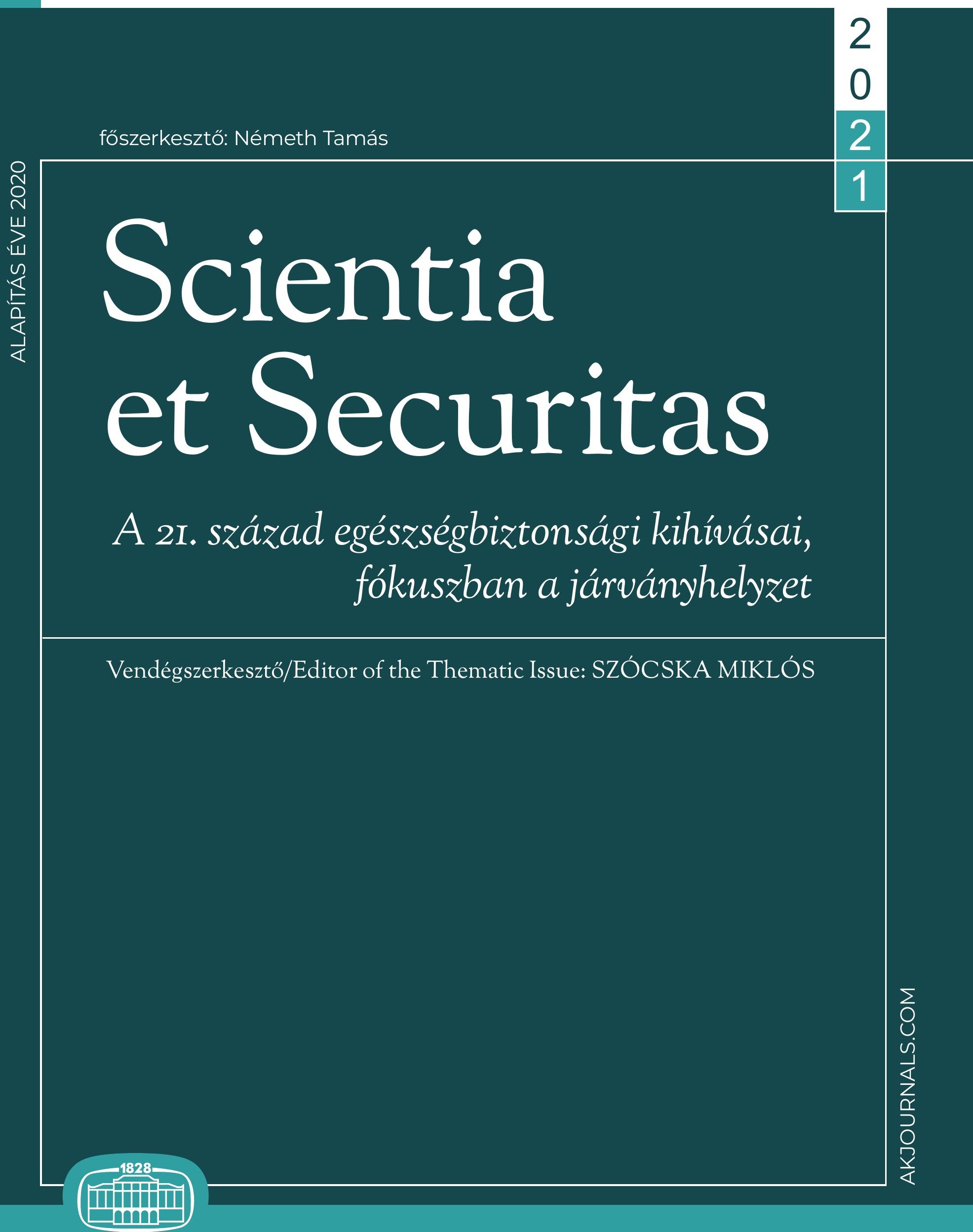




\section{SCIENTIA \\ ET SECURITAS}

2. évfolyam 1. szám - 2021. március

\section{A 21. század egészségbiztonsági kihívásai, fókuszban a járványhelyzet}

Vendégszerkesztö/Editor of the Thematic Issue: SZÓCSKA MIKLÓS

\section{A BELÜGYI TUDOMÁNYOS TANÁCS ÉS A DOKTORANDUSZOK ORSZÁGOS SZÖVETSÉGE LAPJA JOURNAL OF THE ACADEMIC COUNCIL OF HOME AFFAIRS AND THE ASSOCIATION OF HUNGARIAN PHD AND DLA CANDIDATES}

Főszerkesztö/Editor-in-Chief: NÉMETH TAMÁS

Felelős szerkesztö/Managing Editor: SABJANICS ISTVÁN

\begin{aligned} & \multicolumn{2}{c}{ Szerkesztőbizottság/Editorial Board: } \\ & ASZÓDI ATTILA KOLTAY ANDRÁS \\ & BIRKNER ZOLTÁN KOVÁCS GÁBOR \\ & CSÉPE VALÉRIA KOVÁCS MELINDA \\ & DEZSŐ TAMÁS MARÓTH MIKLÓS \\ & DOBÁK IMRE MÓGOR JUDIT \\ & GÁSPÁR MARCELL GYULA PALLO JÓZSEF \\ & GYŐRI ZOLTÁN SABJANICS ISTVÁN \\ & CHARAF HASSAN SZABÓ PÉTER \\ & HALLER JÓZSEF SZÓCSKA MIKLÓS \end{aligned}

Szerkesztöségi titkár/Head of the Editorial Office: KOVÁCS EDINA

$\begin{aligned} \text { Szerkesztőség: } & \begin{array}{l}\text { Editorial Office: } \\ \text { Ministry of Interior } \\ \text { Belügyminisztérium }\end{array} \\ \text { Tudománystratégiai és -koordinációs Főosztály } & \text { Science Strategy and Coordination Department } \\ \text { Cím: } 2090 \text { Remeteszőlős, Nagykovácsi út 3. } & \text { Address: H-2090 Remeteszőlős, Nagykovácsi út } 3 . \\ \text { Tel.: }(+36 \text { 26) 795 } 906 & \text { Phone: }(+3626) 795906 \\ \text { E-mail-cím: scietsec@bm.gov.hu } & \text { E-mail: scietsec@bm.gov.hu }\end{aligned}$

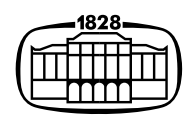

AKADÉMIAI KIADÓ, BUDAPEST 


\section{Előszó}

Az úgynevezett epidemiológiai fordulat a világ alacsony jövedelmû részén is megtörtént évekkel ezelőtt, és mára több ember hal meg krónikus nem-fertőző, életmódhoz köthető betegségekben, mint fertőző, járványos megbetegedésekben.

„A kórokozók elleni háborút megnyertük” - deklarálta több mint két évtizede az amerikai tisztifóorvos. Mivel az emberiség fejlett része a korábbi évtizedek sikeres oltási programjainak biztonságát élvezte, ez a megjegyzés elég volt ahhoz, hogy alábbhagyjon a lelkesedés a fertőző megbetegedésekkel kapcsolatos kutatások iránt, és elapadjon az oltások, antibiotikumok fejlesztését célzó befektetői kedv.

A népegészségügyi szakemberek, járványüggyel foglalkozók ijedten figyelték a folyamatokat, az antibiotikumokkal szemben rezisztens kórokozók terjedését, a globalizáció és a klímaváltozás következtében terjedő vektorokat. Tudták, hogy csak idő kérdése, és az emberiség soha nem látott fenyegetésekkel kell szembenézzen, és azt is tudták, hogy a védelmünk meggyengült. Globális járvány kirobbanása esetén a védőeszközeink korlátosak, és nincsenek megfelelő erőforrásaink, valamint mechanizmusaink a védelem gyors kifejlesztésére. $A z$ egészségügy biztonsági kérdései címú 2016-os könyvfejezetünkben már mi is megírtuk, hogy abban az időben az Egészségügyi Világszervezet (WHO) sürgősségi alapja csak 20\%-ban volt feltöltve! Mára megtapasztalhattuk azt, amit akkor elemzői szemmel fogalmaztunk meg: a világ felkészületlenül várta az elkerülhetetlen világjárványt.

Az emberiség menthetetlenül elbízta magát. Pedig kezdetben még nem voltak oltásellenes celebek, és nem volt kezükben a közösségi média véleményvezérek köré szerveződő hálózatok hírterjesztő ereje sem.

A népegészségügyi szakemberek tudták, hogy valami jönni fog, és annyi kudarc érte őket a döntéshozók meggyőzésében, hogy egyik-másik igazából alig várta, hogy történjen valami. „Nem szabad elvesztegetnünk egy jó kis járványt” - gondolta egyikük, és egy kezdődő járvány egy elkeseredett pillanatában ki is csúszott a száján. A kezdődő járványoktól való félelmükben és a lassú reakciók láttán az elmúlt két évtizedben a népegészségügyi szakemberek négyszer kiáltottak farkast. Emlékszünk a járványok neveire: SARS, MERS, madárinfluenza, sertésinfluenza $(\mathrm{H} 1 \mathrm{Nl})$, nem is beszélve az Eboláról, vagy a riói olimpia alatt fenyegető Zika-vírusról. Ezek mind-mind előrengések voltak, de mivel egyik sem volt az igazi, ezért a népegészségügyi szakemberek a farkast kiáltó pásztorfiú hálátlan szerepébe manőverezték magu- kat, és számos országban minimum parlamenti vitában, de sokban vizsgálóbizottságok foglalkoztak az elhamarkodott vakcinabeszerzésekkel, a gyógyszergyáraktól feláron vásárolt termékek beszerzési ellentmondásaival. A meg-megújuló járványkezdemények során, akinek oltóanyaggyára vagy oltóanyaga volt, nyugodtan ült a készletein. Akinek nem volt, kapkodva vásárolt, vagy kockáztatva kivárt. Az egész járványügy egyfajta szakértői-gyógyszergyári összeesküvésnek tûnt sokak szemében. Farkast kiáltunk, hogy végre igazunk vagy hasznunk legyen. Közben a népegészségügyi szakemberek tudták, hogy egyszer jönni fog, és tehetetlenül figyelték a tehetetlenséget.

És akkor eljött a COVID-19. „Ez most az, vagy még csak egy előrengés?” - gondoltuk a Kínából érkező első hírek hallatán. Ez most Ázsiában marad, mint a SARS-1, vagy a Közel-Keleten, mint a MERS, és nem jön el hozzánk, ez is egy távoli hírfoszlány marad, mint a Zika, vagy elterjed a világban? Senki sem tudta, pedig a kutatóknak ez a kórokozócsalád az a szokásos helyi bajkeverő, akit a körzeti megbízott elsőnek visz be egy kocsmai verekedés után. Ott volt a körözési listán. Mégis álmunkban kapott el minket.

A történet mára ismert, a végkimenetele nem. Velünk marad-e, mint az influenza? Képesek leszünk-e innovatív megoldásokkal megvédeni az emberiséget? Képesek leszünk-e elfogadni, hogy változtatnunk kell magatartásunkon, vagy csak minél előbb el akarjuk felejteni ezt a globális rémálmot? Képesek leszünk-e megküzdeni az oltásellenesség, vírustagadás, maszkellenesség diverziós világmozgalmaival? A fertőzések leküzdése mellett képesek leszünk-e megbirkózni a mindennapok egészségbiztonsági kihívásaival? Képesek leszünk-e megküzdeni azzal, vagy továbbra is tehetetlenül figyeljük, ahogy kontroll nélkül marketingelik az egészségtelen életmódot, hizlalják, dohányzásra buzdítják, itatják, lustítják a világ polgárait, és a kialakuló krónikus megbetegedésekkel sebezhetôvé teszik őket a fertőző betegségekkel szemben, megágyazva a következő világjárványnak is?

Tartozunk annyival a védekezés minden rendü és rangú hősének és áldozatának, hogy tanulunk mindabból, ami történt. Ez a kiadvány is azért született meg, hogy a tapasztalatokat összefoglaljuk, és felkészültebben várjuk az elkerülhetetlent, az egyre valószínúbb világjárványokat.

Szócska Miklós vendégszerkeszto"

A cikk a Creative Commons Attribution 4.0 International License (https://creativecommons.org/licenses/by-nc/4.0/) feltételei szerint publikált Open Access közlemény, melynek szellemében a cikk bármilyen médiumban szabadon felhasználható, megosztható és újraközölhető, feltéve, hogy az eredeti szerző és a közlés helye, illetve a CC License linkje és az esetlegesen végrehajtott módosítások feltüntetésre kerülnek. 